\title{
THE CITY SECRETARY'S OFFICE OF FRANKFURT-ON-THE-MAIN
}

\author{
BY MARTIN H. DODGE \\ Columbia University
}

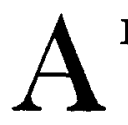

$\mathrm{HIGH}$ official in American city government recently said: "After all there is no genius in German city government. It is different to be sure, and interestingly so for the American student; but beyond this it is only an historic growth, encompassed by ubiquitous German system, applicable only to German conditions, and without a solution for American municipal ills." Such an opinion comes somewhat as a shock to the ardent city reformer of this country, who has seen in German municipal efficiency the incarnation of all the virtues of municipal administration. It has been generally believed that American cities have much to gain from German experience. But wherein the gain consists is a question which demands closer scrutiny of details and comparison of conditions than reformers have generally felt themselves obliged to consider.

An interesting example of German municipal administration is found in the department known as the Stadtkanzlei, or city secretary's office, of Frankfurt-on-the-Main. Although this department, in one form or another, is common to the governments of French and English cities, it is rare in Germany and practically unknown in the United States. From the American point of view, in fact, it stands as a novel device of municipal organization. It is Frankfurt's "private secretary." It opens the government's mail, writes its letters, receives its visitors, oversees its employes, checks official inconsistencies, and supplies the qualifying adjectives as well as many of the data for official utterances. In short, the city secretary's office is at once the agent, the clerk, and the critic of the city administration.

To carry out its functions it is divided into seven bureaus and employs about $85 \mathrm{men}$. This somewhat extensive organization, however, is a matter of recent development. The office began its history in 1869 , without special organization, employing less than a dozen men. Tht actual work was in charge of a director who was responsible to the mayor. The functions were simple, involving for the most part the care of the communications and accruing documents of the administrative board or magistrat and the mayor.

The development of the office came with the growth of the city. In the thirty years following 1869, Frankfurt's population increased by more 
than 300 per cent (from 90,000 to 280,000 ). Its administrative problems increased accordingly, and by 1900 the enlarged demand upon the secretary's office had crystallized this branch of the administration into a well organized department of four bureaus: Civil service and secretarial, clerical, accounting, and registration and correspondence. By 1904 further demands made it necessary to add two more bureaus: magistrat's writing room, and messenger service. Two years later the seventh and final division was created-the book and document binding bureau.

As the names of these various bureaus suggest, the work of the office during these years of development became identified with the essential elements of a German city administration-that is, with the complicated features of administrative routine. In this capacity the city secretary's office performs three functions, which will be considered in turn.

\section{CLEARING HOUSE FOR ROUTINE}

The first and most striking function that the office performs is to act as a great clearing house for intra-governmental routine. Ordinary clerical operations, which in most cities are carried out separately in the various governmental departments, are in Frankfurt centralized in the city secretary's office. Specifically under this head comes the handling of government mail. Every parcel of government mail of whatever nature is delivered first of all to the city secretary's office and is received by the bureau of messenger service. That part of: it which is expressly addressed to a particular department is immediately delivered by the messenger service to that department. All other mail is turned over to the registration and correspondence bureau, which opens and classifies it, and with the aid of messenger service, delivers that part of it about which there is no question as to appropriate destination. The remainder (about 50 per cent of all mail) is turned over to the city secretary himself who answers about half of it on his own authority and refers the remainder to the mayor, or through the mayor, to the magistrat.

In a similar manner the city secretary's office disposes of all official documents. Legislative proposals, amendments, departmental reports, and all other official papers which naturally come to the magistrat, as the most important arm of the city government, are sent first of all to the city secretary. It is his personal duty to examine them as to form and substance, make necessary corrections, and set them up as the "orders of the day" for the magistrat's meeting.

Further, under the "clearing house" function may be cited the work of the magistrat's writing room. The writing room is a central office to which all city departments go for official letter writing and multiple printing of circular letters and notices. Although not the most important bureau of the department, it employs twice as many men as any other, having a force of forty employes including a director and two assistants, 
a clerk of the bureau, four lithographers, and thirty-two typists. The administrative procedure followed by the writing room is so typical of that of the whole department that it is perhaps worthy of somewhat detailed description.

In the first place, whenever a department wants a letter written it sends a copy of the same either in long hand or shorthand to the writing room. Here it is stamped to show the exact time at which it was received. Next it is entered in a book of record called the Kontrolle, and the following data are recorded: date of receipt, department for which work is to be done, number of pieces, short description of contents, and name of typist to whom the draft is now submitted for writing. Upon finishing the work the typist signs his name to the draft and submits the original and the finished copies to one of the two assistants to the director, whose business it is to inspect the finished work. If he finds it satisfactory, he signs his initials at the bottom of the original draft and then records these further data in the Kontrolle: The time at which the material was returned by the typist, number of half sheets written or time consumed for the work and the proofreading, and any remarks that are necessary. The finished work is then sent on through the messenger service to the department for which it has been done.

This is the procedure for writing single letters. For multiple printing and lithographic work it is much the same. The form of the work, in all but special cases, is determined by ordinance specifications. Payment is made monthly to the city secretary's office by the various departments, and the prices for different kinds of work are likewise determined by ordinance.

From the standpoint of efficiency of the service, the work of every employe is carefully guarded and measured. This is accomplished largely through a system of reports. The typist who receives a piece of work must record in a special report folder or "assignment book" the following facts: time at which he receives the matter, department for which he writes, identification number of the letter or document, time at which he returns it to the inspector, and number of half sheets written or the time consumed. In addition to these items there must also be recorded a certification by another clerk as to the correctness of the statement. At the end of each week these facts must be summarized in a report in accordance with the specifications of the city ordinance. This report becomes the first basis for the measurement of work. A week's work for the employe consists of five and four-fifths days, and each day the typist is supposed to deliver thirty-two half sheets of completed work. If he delivers more than this amount he is awarded extra pay; if less, he is reprimanded or perhaps dismissed. In either case it is essential that the exact amount be recorded. In case the employe's work is such that it can be measured only by time, as is true of much of the lithographers' 
work, then the employe must fill out a special blank which includes an equation method of transforming time into half sheets.

At the end of every month the facts of the weekly reports are summarized into a monthly report, the relevant facts of which are in turn transferred to a general statement for the entire bureau. It is upon the basis of this last statement, drawn up in accordance with an ordinance classification, that salaries are paid. Before this statement is sent to the finance department, however, all employes to whom money is due are required to sign their names opposite the amounts accorded to them. The statement is then recorded by the accounting bureau of the city secretary's office and from there sent to the finance department where it is recorded in a similar manner. Finally, when the finance department is ready to make payment, one clerk from the writing room is sent to the department. He signs a certificate for the receipt of all moneys and then delivers to each employe the amount which is due him. So much for the administrative procedure of the writing room.

It is natural that the department which handles official documents and correspondence should be occupied also in preserving these materials. The office, through its document and bookbinding bureau, for instance, puts into permanent form the copies or the originals of correspondence, minor reports of committees, and stenographic or typewritten memoranda of all official conversations and interviews. This branch of the service employs fourteen book and document binders. The civil service and secretarial bureau, employing six men, administers the magistrat's special library of documents and reports, as well as the circulating library of books of governmental and local interest. It is the custodian of the official "book of ordinances" (Bürgerbuch), and a book of record for all resolutions and actions of the magistrat's deputations and commissions. It also gathers and files for reference copies of speeches, magazine articles, and newspaper clippings on matters of particular governmental interest.

Finally, in connection with the clearing house function, the city secretary himself acts as the official recording secretary at magistrat meetings. In this capacity he becomes a confidential and authoritative center of information on all magistrat business. The secretary or one of his assistants acts likewise as the recording secretary at the meetings of the numerous magistrat commissions. Besides this work the office performs important administrative duties for all special committees on celebrations and municipal entertainments, the insurance commission, the general commission on charity and aid institutions, the art museum commission and the commission on the historical development of the city.

CIVIL SERVICE FUNCTIONS

The second general group of duties performed by the city secretary's office may be summed up under the head of "civil service functions." 
Frankfurt's civil service is regulated by both state laws and municipal ordinances. A commission on civil service examinations and another on courses of study for employes are appointed by the magistrat. But beyond such duties as the actual hearing and passing upon the examination and the teaching of the courses offered, the city secretary's office performs all the routine work involved. It receives and answers inquiries concerning positions and employment, furnishes the somewhat elaborate blanks which are required to be filled out by applicants, examines these blanks on their return, accepts or rejects them as they measure up to requirements, and then arranges with the applicants for the time and place of their examination. In the examination itself the office has charge of similar routine duties, leaving no more work to the examination commission than is necessary to the exercise of its judgment as to the fitness of the candidates. But it should be added that the director of the civil service and secretarial bureau is also one of the five members who constitute the examination commission referred to above. Consequently the city secretary's office is represented on the side of policy as well as that of administration of the civil service.

Following the acceptance of the candidates into the government service, the city secretary's office enters into further relations with them. The secretary himself, for instance, acts as the general supervisor of the entire civil service. By this it is not meant that he has power to interfere directly with the work of any department over the head of its chief; but rather that he is an efficiency expert whose business it is to establish and maintain an esprit de corps and a high order of service throughout the organization. In accordance with this object the secretary keeps in touch with the general standard of service as well as the work of the individual employe through the efficiency and service records already referred to. He also maintains an effective co-ordination of the whole through the shifting of clerks and office employes according to the changing needs of the different departments. This method of transfer tends to eliminate the stress and waste of seasonal variations of work and establishes an equilibrium of service.

The secretary, through the different bureaus of his department, is also responsible for the following civil service functions: furnishing of necessary information upon which grades of compensation are established, securing proper publicity for the classifications determined upon, verification of the employment budget and city payrolls, and administration of accident and sickness insurance funds for city employes as well as widow and orphan moneys. Since insurance is such an essential factor in the life of the German citizen, this last operation constitutes an important service of the secretary's office. 


\section{EDITORIAL WORK AND DRAFTING}

The third, and from the standpoint of governmental policy, the most important function of the city secretary's office is editorial work and legislative drafting. It was pointed out above that all government mail passes through the central office and that the secretary himself answers about one fourth of it and exercises some discretion in disposing of the remainder. This is an incidental authority, but it is none the less important; it is likewise exercised in the matter of official documents. The government is scrupulously careful about the form of its official utterances and communications, and the advantage for this purpose of having a central expert under whose inspection all such matters come is obvious. The gain is equally clear of having a central figure whose relation to the entire legislative and administrative activities of the city is such as to constitute him a competent critic of ill and well-advised proposals. The practical effect of his activity is seen in the fact that less than six per cent of the legislative proposals that reach the magistrat are rejected by that body.

An examination of incoming documents shows that on an average 60 per cent of such matters are reports from the city department and other reports from committees and citizens sent in at the request of the magistrat. These reports are made out on forms furnished by the secretary's office or provided by the department itself. The city secretary, in transmitting them to the magistrat, does not alter their substance; he sees to it, however, that they are in proper form and classifies them to facilitate logical consideration. The remaining 40 per cent of the documents are matters of initiative and original suggestion, and as such require more careful attention. About one fourth of these are not acted upon by the magistrat at once but are made subjects of research and investigation by the secretary's office, or through this office, by technical experts, as the case may require.

As stated above, the secretary or one of his assistants acts as the recording secretary at magistrat-commission meetings. In this capacity the office writes up the minutes of such meetings and thus furnishes much of the material which constitutes the reports of these bodies. It performs similar functions for the Stadt-Bibliothek and the Stadt-Archiv, the two other departments, besides the secretary's office itself, which are directly under the mayor's supervision; it writes all reports and recommendations of the commissions on aid and charity institutions and on hospitals; and lastly, it puts into final form for the consideration of the magistrat, the annual budget proposals of the finance department and all reports pertaining thereto.

These operations of the city secretary's office relate to documents coming to the magistrat from outside sources. But a similar practice is followed in regard to those issuing from the magistrat. As is true of the incoming material, much of that which goes out is also of a routine nature and concerned with frequently recurring matters. To facilitate the 
handling of such affairs, printed forms, known as Akten or Protokolle, are provided. These are filled out by the secretary's office and sent to their proper destination in accordance with directions from the magistrat. For some matters the forms are very complete, requiring the addition of only a few words; for others, they consist merely of an outline. Among the items for which they are used, the most common are formal announcements from the magistrat to the city council and notifications to individuals concerning election to office, appointments, pensions, and contracts.

Work requiring somewhat more initiative and discretion on the part of the secretary's office is that of investigation and research on legislative proposals coming from the magistrat or from individual magistrat members. In this connection the secretary, assisted by three officials from the civil service and secretarial and the clerical bureaus, prepares briefs, and signs the resolutions of the magistrat and magistrat-committees, and drafts the magistrat's reports, communications and statements.

Besides the actual work of composition, this involves ultimately the editorship of four publications. The first of these is the report of the magistrat to the city council. This report is concerned with the immediate affairs of government about which the magistrat thinks the council must or ought to be informed. It is issued whenever such matters arise, which experience shows to be about six times a month. The nature of the reports varies. Sometimes they are mere reproductions of ordinances passed by the magistrat; at other times they are paraphrased accounts given by the secretary on the magistrat's procedure on a certain point. Sometimes they constitute pamphlets of twenty or thirty pages; at others they are only single sheets of one hundred words or less.

\section{THE "ANZEIGE-BLATT"}

The second publication edited by the city secretary's office is the Anzeige-Blatt, a semi-weekly official announcement by the government to the people. It is concerned with those matters about which the magistrat decides there should be publicity. A copy taken at random, for instance, includes on the first page a notice to merchants and another to manufacturers requesting the proper observance of the occasion of the Kaiser's expected visit. On the remaining dozen pages of the bulletin are found such matters as announcements of births, deaths, marriages, and engagements, notices from the magistrat and several of the city departments on matters relating to streets, municipal rooming and apartment houses, the city pawnshop, and the Römer Rathaus.

The third and fourth publications edited by the secretary's office are, respectively, the annual report of the magistrat to the city council (Jahresbericht), and the official book of ordinances (Bürgerbuch). The former is a comprehensive volume of some 450 large-sized pages, presenting a careful review of the entire activity of the government for the year. It is compiled from detail reports from the various departments, bureaus 
and commissions, with a general introduction by the mayor. The latter is a compilation of all the laws and ordinances governing the city, which are subject to constant change and are published in book form annually or biennially. The complete revised copy constitutes a book of 975 pages.

The three general functions which have been sketched above are obviously of sufficient importance to bring the city secretary's office into considerable prominence in city affairs. It remains to speak of one further activity which illustrates its unique and pivotal position. The city secretary's office stands literally at the door of the city government; it is the administration's "outer office." If a visitor or citizen wishes to interview the authorities of Frankfurt he is directed first of all to the city secretary's off.ce. And frequently he need go no further. If, however, the functionaries of this office cannot satisfy his needs, he is then escorted by one of the secretary's city messengers to a more appropriate authority. At all events, the city secretary holds the keys to the offices of his fellow officials, including even that of the mayor. It seems, however, that his responsibility is such as to prevent any despotic use of the power involved. In the position of official "hand-shaker" for the city government, he stands as a man of business ability, of tact, and of allknowledge on city affairs; the city secretary is probably better acquainted with the details of Frankfurt's administration than any other city official, not excluding the mayor.

In conclusion, it seems obvious that the hand of genius is not apparent in the city secretary's office. The department is unique and interesting. But it is not the deliberate invention of an all-seeing mind. Its present organization is not based on theory; it is the natural outgrowth of the exigencies of operation and management. The office has seven bureaus but it performs only three general functions. It is an example of extreme centralization of activities generally administered by separate departments. But its success, for it is admittedly successful, and the lesson of German municipal government which it has to offer, lies neither in its organization nor its functions, but in its operation. The illustration from the magistrat's writing room is sufficient to show the nature of its operation. Every detail of work is standardized that can be standardized. The administration becomes habitual and runs of itself. The energies of the directing staff are expended in inventing new methods of standardizing new duties. Though such a system does not preclude progress, it does not on the other hand encourage the initiative of the employe. It has been a success in Frankfurt; but that it might be a success in this country depends upon whether or not the character of the American rank and file can be reduced to the necessary calibre of the martinet. It is a splendid illustration of German method, German precision, German detail. Most Americans would regard with question a fabric woven so largely of red tape. 